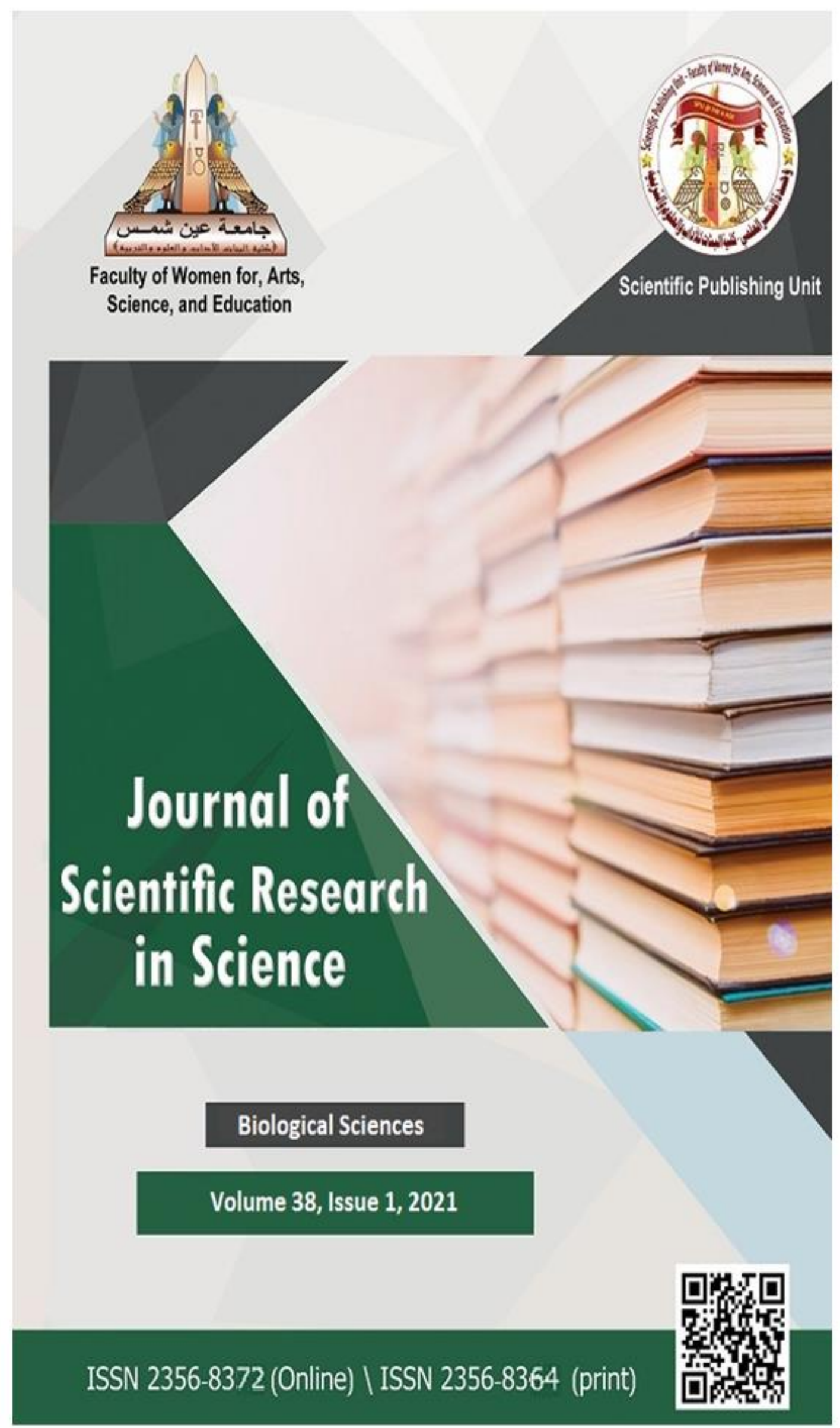




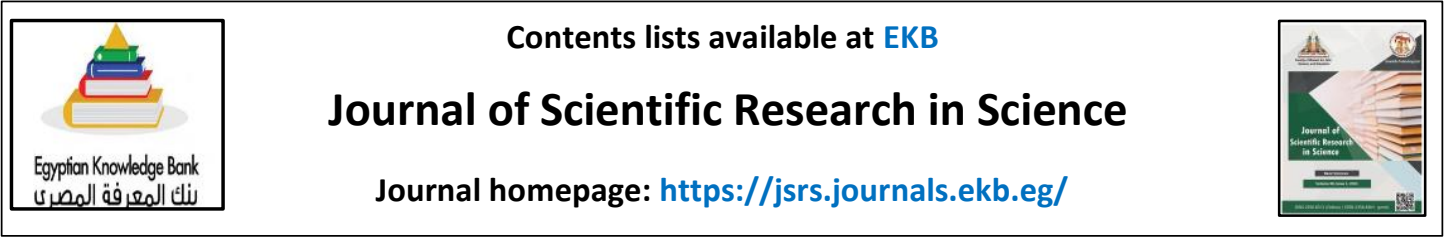

\title{
Albumin nanoparticles Preparation, Characterization and In-Vitro Safety Evaluation
}

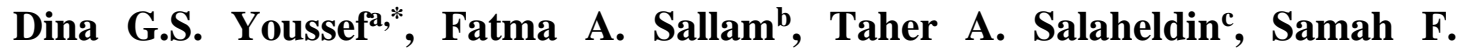
Darwish $^{a}$, Abeer E. El-Metwally ${ }^{\text {, Khaled Y. Farroh }}{ }^{\mathrm{e}}$, Adel S. Amin ${ }^{\mathrm{a}}$

a. Biotechnology Research Unit, Animal Reproduction Research Institute, Egypt.

b. Faculty of Women for Arts, Science and Education, Ain Shams University, Egypt.

c. Nanotechnology and Advanced Material Central Lab, Agriculture Research Center, Egypt; Mostafa Elsayed Nanotechnology Research Centre, British University in Egypt, Egypt.

d. Immunology Unit, Animal Reproduction Research Institute, Egypt.

e. Nanotechnology Department, Agricultural Research Center, Giza, Egypt.

\begin{abstract}
:
The goal of this study was to prepare and characterize albumin nanoparticles to be later used as a drug delivery system. The utilization of nanoparticles as a delivery system for antimicrobial drugs has arisen recently which solve many problems and enhance the traditional treatment with this antimicrobial drugs. In this study, nanoparticles of bovine serum albumen were successfully obtained using a coacervation process (separation of proteins in two liquid phases in colloidal systems). The prepared nanoparticles were nearly spherical in shape and have smooth surface as determined by Transmission Electron Microscopy (TEM). The sizes of the obtained nanoparticles were $70 \pm 10 \mathrm{~nm}$ with negative surface zeta potential. Additionally, the in vitro safety of albumin nanoparticles has been demonstrated. Both cytotoxicity and genotoxicity studies indicated that, there is no observed toxic effect of nano-albumin on lymphocyte cell line. Also, the results showed that the albumin nanoparticles enhances and promotes the response of immune system.
\end{abstract}

Keywords: albumin nanoparticles, cytotoxic, genotoxic, proliferation activity

\section{Introduction:}

Nanotechnology is the science dealing with the atomic, molecular and macromolecular levels of particles at the nano scale to provide a fundamental understanding of characters of these particles. Moreover, it is used to create and

*Corresponding author: Dina G.S. Youssef, Biotechnology Research Unit, Animal Reproduction Research Institute, Egypt.

E-mail: dndn_77777@yahoo.com 
innovate many devices and systems that have innovative phenomena and functions because of their new very minute size $[1,2,3]$.

Nanostructure of nanoparticles, biomaterials in particular, have new specific physicochemical properties such as large surface area verses mass ratio, ultra-small and controllable size, strong reactivity, and functionalize forms and these make them could be used in the applications of antimicrobial preparations, thus resolving problems encountered in conventional antimicrobial therapy [4,5]. Also the nanoparticles increase the therapeutic efficacy of these antimicrobials, incompetent delivery could lead to insufficient therapeutic index with localized and systemic side effects. So, the necessity for good antimicrobial drug delivery system to deliver the drug to the specific organ that harbors infection is critically important $[6,7]$. Recently, utilization of nanoparticles as a delivery system for antimicrobial drugs has arisen as a new alternative that hopefully could not only minimizes the toxicity of these antimicrobial drugs but also enhances therapeutic efficacy [6].

Albumin is the most plentiful protein in human plasma; it constitutes more than $50 \%$ of human plasma proteins [8]. Albumen molecule consists from three parts working together to give albumin its discrete binding properties. Albumin contribute for $75 \%-80 \%$ of the normal colloid oncotic pressure of plasma. It contains long chain of solubilizing fatty acids, carriage of nutrients to cells, and also keeping the plasma $\mathrm{pH}$ in balance [9]. It can be used in many different formulations as nanocarrier, nanospheres and nanocapsules which all are biodegradable [10]. Many drugs and endogenous molecules can easily bind to albumin [11, 12], which acts as a depot and carrier system [10]. Its characteristic solubility which reaches up to $40 \% \mathrm{w} / \mathrm{v}$ at $\mathrm{pH}$ 7.4 , nominate it as good macromolecular carrier having the ability to react with wide variety of drugs. Moreover, its stability at both wide-ranging of $\mathrm{pH}$ (4 to 9) and at heat $\left(60^{\circ} \mathrm{C}\right.$ for 10 hours) without any harmful effects [11, 13]. Bovine Serum Albumin (BSA) is one of the albumin proteins that is able to make complexes with different drugs and its non-toxic, biodegradable and non-immunogenic characters make it safely used as drug carrier $[14,15]$.

Our goal in this study was the preparation and characterization of albumin nanoparticles to be later used as a drug delivery system. Moreover, the cytotoxic and genotoxic effects of the prepared nano-albumin will be evaluated in vitro. 


\section{Materials and Methods:}

\subsection{Preparation of nano-albumin:}

Bovine Serum Albumin (BSA) nanoparticles were prepared from Bovine serum albumin, Fraction V, purity min. 98\% (BioShop Canada Inc) at room temperature using an ethanol desolvation technique [16]. In brief: $1 \mathrm{~g}$ of BSA was dissolved in $5 \mathrm{~mL}$ of $10 \mathrm{mM} \mathrm{NaCl}$ (BioShop Canada Inc) with stable stirring at 800 rpm for $10 \mathrm{~min}$ at room temperature. After total dissolution, the $\mathrm{pH}$ of the solution was adjusted to be 9.3 with $1 \mathrm{~N} \mathrm{NaOH}$ and stirred for $5 \mathrm{~min}$. Then the additions of ethanol (BioShop Canada Inc) to aqueous phase drop-wisely to dissolve this of BSA solution with continuous stirring rate $(800 \mathrm{rpm})$. The addition of the ethanol (1-2 $\mathrm{mL} / \mathrm{min}$ ) was until the BSA solution converted to turbid solution. Then addition of $8 \%$ glutaraldehyde (BioShop Canada Inc) as cross-linking agent was to form stable BSA particles. The achieved nano-albumin particles were washed three times by deionized water $\left(\mathrm{dH}_{2} \mathrm{O}\right)$ by centrifugation then the nanoparticles were re-suspended in an equal volume of phosphate buffered saline (BioShop Canada Inc). The given particles were lyophilized until used.

\subsection{Characterization of resulted albumin nanoparticles:}

Both preparation and characterization of albumen nanoparticles were performed at Nanotechnology and Advanced Materials Central Lab (NAMCL), Agricultural Research Center, Giza, Egypt.

\subsubsection{Assessment of morphology of prepared nano-albumin:}

To assess the morphology of the obtained albumen nanoparticles, the diluted nanoparticles solution was firstly ultra-sonicated to decrease the aggregation of particles for $5 \mathrm{~min}$. Then, three drops of the solution were put on carbon coatedcopper grid and left to dry at room temperature. The morphological evaluation of BSA nanoparticles was detected by capturing the deposited nanoparticles using High Resolution-Transmission Electron Microscope (HR-TEM) with voltage of $200 \mathrm{kV}$ (Tecnai G2, FEI, Netherlands).

\subsubsection{Assessment of the chemical properties of achieved nanoparticles:}

$\mathrm{X}$ ray Diffraction (XRD) technique was used to assess the chemical structure of the prepared BSA nanoparticles. The XRD pattern was recorded in the scanning mode (X'Pert PRO, PANalytical, Netherlands) operated by $\mathrm{Cu} \mathrm{K}$ radiation tube $\left(=1.54 \mathrm{~A}^{\circ}\right)$ 
at voltage of $40 \mathrm{kV}$ and current of $30 \mathrm{~mA}$. The resulted diffraction pattern was interpreted by the ICCD standard library installed in PDF4 software.

\subsubsection{Estimation of the zeta potential and the particle size distribution:}

Dynamic Light scattering (DLS) technique was utilized to detect the zeta potential and the average particle size distribution that were measured by Zeta Sizer (Malvern, ZS Nano, UK). The diameter and the zeta potential of the nanoparticles were measured after dispersion in ultrapure water $(1 / 10)$ at $25^{\circ} \mathrm{C}$ by dynamic light scattering angle of $90^{\circ} \mathrm{C}$. Both particles sizing and zeta potential measurements were measured three times for each batch of particles and the results were the average of three measurements.

\subsection{Assessment of the cytotoxicity effect of nano-albumin particles using $M T T$ assay:}

The cytotoxicity was assessed by a modified $M T T$ assay [17]. Briefly, the lymphocytes were prepared [18]; lymphocyte cells were seeded into 96 well plates at a density of 5000 cells per well followed by overnight incubation. Then, the medium was aspirated and fresh RPMI 1640 medium containing different concentrations of nano-albumin ranging from $(0.0001$ to $10000 \mu \mathrm{g} / \mathrm{mL})$ per well was added. The plate was incubated for $72 \mathrm{~h}$ at $37^{\circ} \mathrm{C}$ in a humidified atmosphere with $5 \% \mathrm{CO}_{2}$. After incubation, $25 \mu \mathrm{l}$ of a $5 \mathrm{mg} / \mathrm{mL}$ MTT (3-[4,5- Dimethylthiazol-2-yl]-2,5diphenyltetrazolium bromide) solution was added to each well, and the plates were incubated for an additional $4 \mathrm{~h}$. After that, to dissolve the formazan crystals, $100 \mu \mathrm{L}$ of Dimethyl sulfoxide (DMSO) (Sigma- Aldrich, St Louis, USA) was added into each well, stirred, and the absorbance of the cell suspension at $540 \mathrm{~nm}$ was determined using a FLUO star Omega Microplate Reader (BMG Labtech, Offenburg, Germany). Evaluation of cytotoxicity was done by comparing the absorbance of treated cells versus the untreated controls.

\subsection{Assessment of Genotoxicity of prepared nano-albumin using comet assay:}

The DNA integrity was evaluated using the alkaline comet assay [19]. Briefly, $20 \mu \mathrm{L}$ whole blood was added to $1 \mathrm{~mL}$ RPMI 1640 in a microcentrifuge tube, then, $100 \mu \mathrm{L}$ Ficoll histopaque (Sigma- Aldrich, St Louis, USA) was added below the blood/media mixture. After centrifugation for $30 \mathrm{~min}$ at $1300 \mathrm{x} \mathrm{g}$, collect the middle layer (lymphocyte), wash with PBS for two times, the pellet was resuspended in $\sim 1$ 
$\mathrm{ml}$ of RPMI and counted over a Haemocytometer. $200 \mu \mathrm{l}$ containing $5 \times 10^{4}$ cells in RPMI-1640 culture medium were seeded into 96 well plates and $100 \mu 1$ of different concentrations of nano-albumin ranging from 0.0001 to $10000 \mu \mathrm{g} / \mathrm{mL}$ was added and incubated for $24 \mathrm{~h}$. After incubation, the alkaline comet assay was proceeded to approximately $1 \times 10^{4}$ cells/ $10 \mu \mathrm{l}$ from the cell suspension. Visual scoring was performed according to tail size. Cells were classified into five classes ranging from undamaged (grade 0), to maximally damaged (grade 4) [20].

\subsection{Assessment of the effect of the prepared nano-albumin on the immune response using Lymphocyte proliferation activity assay:}

The proliferation activity of lymphocytes was determined by measuring mitochondrial activity using the MTT reduction method [18]. Briefly, lymphocyte proliferative response was estimated by stimulation of lymphocyte with phytohaemagglutinin (PHA, SIGMA) at concentration of $(15 \mathrm{ug} / \mathrm{ml})$ and cultured in 96 well tissue culture plate with $10 \%$ fetal calf serum. Different concentrations of nanoalbumin ranging from $(0.0001$ to $10000 \mu \mathrm{g} / \mathrm{mL})$ per well were added and incubated for $72 \mathrm{~h}$ at $37^{\circ} \mathrm{C}$ in a humidified atmosphere with $5 \% \mathrm{CO}_{2}$. MTT $(5 \mathrm{mg} / \mathrm{ml})$ was added as $1 / 10$ of the media /each well followed by incubation at $37{ }^{\circ} \mathrm{C}$ for 4 hours in a humidified atmosphere with $5 \% \mathrm{CO} 2$. Then, lyses of cells using lysis buffer and the absorbency was read at $590 \mathrm{~nm}$ in an enzyme immunoassay multi well photometer.

\subsection{Statistical analysis:}

Statistical analysis of results was determined using one way ANOVA employing a completely randomized design [21].

\section{Results and Discussion:}

\subsection{Preparation of BSA nanoparticles:}

Nano-albumin was successfully prepared based on the simple coacervation process (the desolvation technique) as described earlier. The technique was reported to be simple for preparation of nano-albumin. Moreover, the resultant nano-particles were stable in size, surface zeta potential and morphology. This technique involves the separation of the liquid phase of aqueous homogenous albumin solution. This separation leads to the formation of nanoparticles in the colloidal (or coacervate) phase [22]. In addition, the size of the nanoparticles formed by this technique can be 
changed based upon the various technique parameters including concentration, $\mathrm{pH}$ of BSA solution, volume and rate of ethanol addition [23, 24].

\subsection{Characterization of nano-albumin:}

\subsubsection{High resolution transmission electron microscope (TEM):}

The image of transmission electron microscopy (TEM) has revealed that the synthesized nano-particles are nearly spherical in shape and have smooth surface as shown in Fig. 1a. A similar conclusion was previously published by Rahimnejad. [25] but this technique, the formed nanoparticles size can be altered as a result of the various parameters of the technique, such as $\mathrm{pH}$ and concentration of BSA solution, rate and volume of ethanol addition and he found that, as the concentration of BSA increased, the particle size was decreased and the minimum particle size was at BSA concentration $(30 \mathrm{mg} / \mathrm{ml})$. He also found that the particle size may not be influenced with the change of $\mathrm{pH}$. Also, the rate of addition of ethanol on particle size was examined and it was found that there was no influence of ethanol concentration reflected on particle size and finally the size of the particles was expected to reduce with increasing the trend of agitation speed so the minimum size of particles was (138 $\mathrm{nm})$ at agitation speed of $500 \mathrm{rpm}$. In the presented study, nanoparticles with average size $78.4 \mathrm{~nm}$ with the use of $20 \mathrm{mg} / 1 \mathrm{~mL}$ BSA at $\mathrm{pH} 9.3$ and $\sim 1-2 \mathrm{~mL}$ of $100 \%$ ethanol with $500 \mathrm{rpm}$ agitation were obtained.

\subsubsection{X-ray diffraction:}

X-Ray powder diffraction patterns of BSA nanoparticles are shown in Figure 1b. No peak was detected in the diffractograms. BSA nanoparticles are comprised of a dense network structure of interpenetrating polymer chains cross-linked to each other by glutaraldehyde counter ions [26]. The XRD showed greater disarray in chain alignment in the nanoparticles after crosslinks.

\subsubsection{Determining Particle Size and Surface Zeta Potential:}

Fig.1: 1c, 1d represents the particle size distribution curve as obtained by DLS measurements. The BSA nanoparticles surface charge, zeta potential, was (- $30 \mathrm{mV})$ and the size $(69.9 \mathrm{~nm})$ as measured by DLS technique $[17,26]$. The bovine serum albumin (BSA) is an acidic protein where it carries a negative zeta potential in $\mathrm{pH} 9.3$ and thus allows the positive molecules to bind to BSA nanoparticles [27, 28, 29]. 
(a)

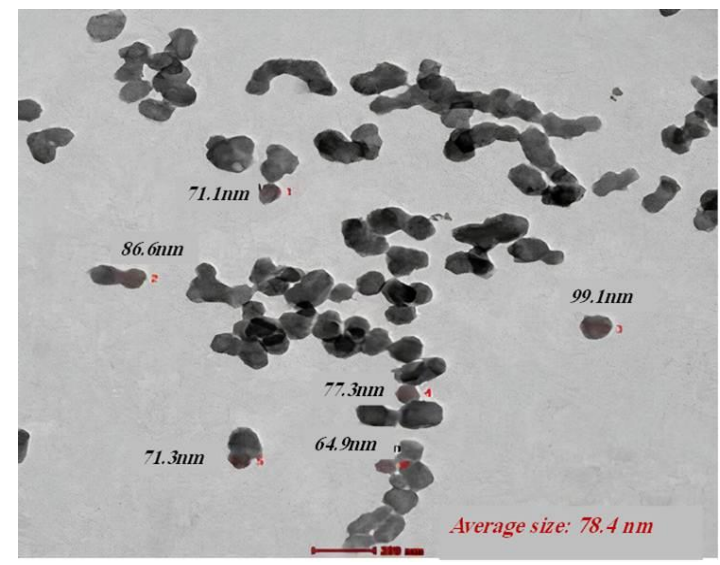

(c)

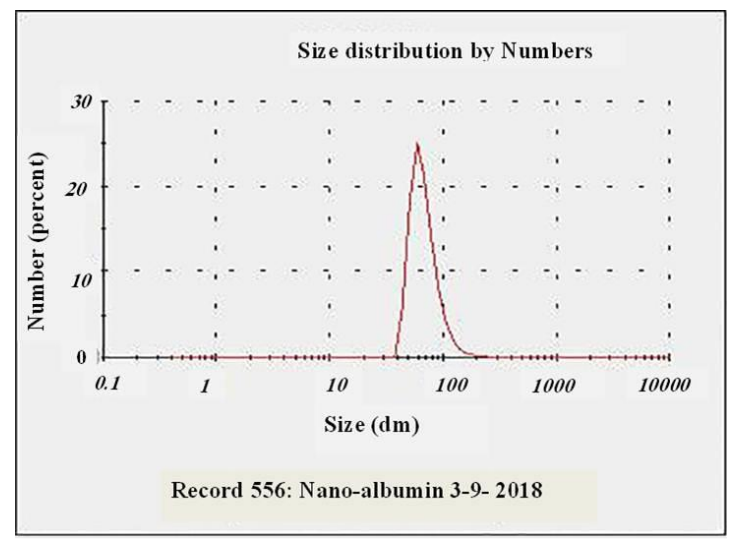

(b)

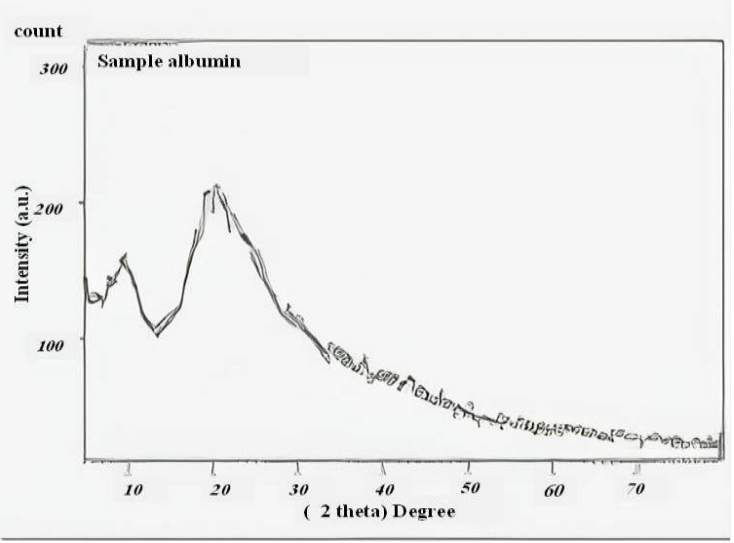

(d)

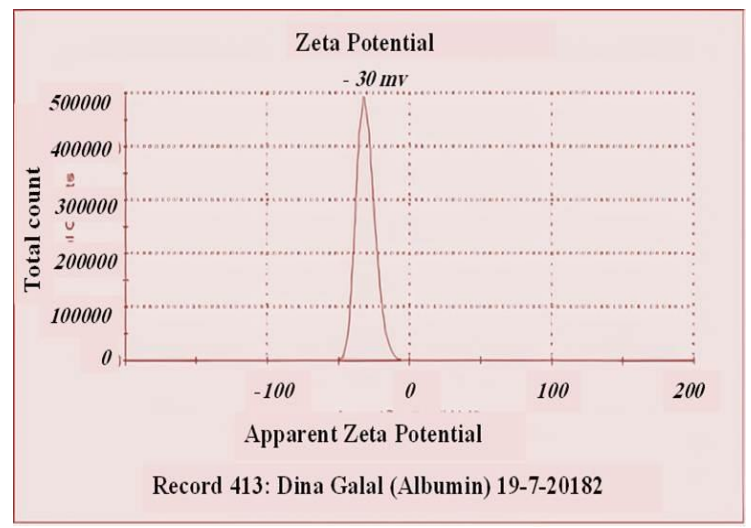

Fig. 1: Characterization of prepared nano-albumin (a) TEM image of prepared Nanoalbumin (b) X-ray diffraction patterns of prepared nano-albumin, the intensity of XRD background is high at the corresponding degree of the amorphous structure of prepared nano-albumin.(c) Size determination of prepared nano-albumin (d) Zeta potential of prepared nano-albumin.

\subsection{In vitro cytotoxicity (MTT assay):}

The cytotoxicity of prepared albumin nanoparticles was evaluated using MTT assay using different concentration ranged from $(0.0001 \mu \mathrm{g} / \mathrm{ml}$ to $10000 \mu \mathrm{g} / \mathrm{ml})$. As shown in table (1), it was concluded that nano-albumin has no cytotoxicity effect on lymphocytes. Similar findings were also reported by many authors [25, 30, 31]. This could be attributed to the fact that albumin is nontoxic, biodegradable and biocompatible which is also able to form noncovalent complexes with different molecules, natural and synthetic [32]. 
Table (1): Mean \pm SE of MTT test readings of the cytotoxic effect of different concentrations of prepared nano-albumin on lymphocytes cell.

\begin{tabular}{|l|l||}
\hline Conc. of nano-albumin $\boldsymbol{\mu g} / \mathbf{m l}$ & Mean $\pm \mathbf{S E}$ \\
\hline \hline Control & $1.599 \pm 0.026$ \\
\hline \hline 10000 & $1.17 \pm 0.04$ \\
\hline 1000 & $1.12 \pm 0.041$ \\
\hline 100 & $1.25 \pm 0.23$ \\
\hline 10 & $1.26 \pm 0.21$ \\
\hline 1 & $1.07 \pm 0.094$ \\
\hline \hline 0.1 & $1.23 \pm 0.09$ \\
\hline 0.01 & $1.15 \pm 0.22$ \\
\hline 0.001 & $1.24 \pm 0.08$ \\
\hline 0.0001 & \\
\hline \hline
\end{tabular}

\subsection{In vitro genotoxicity (DNA Integrity test or comet test):}

To exclude any genotoxic effect for the prepared nano-albumin, comet assay was used to detect any DNA degradation. The comet assay was used to detect the DNA fragmentation at the level of single cells (genotoxic effect). In our study, the comet assay didn't observe any significant genotoxic effects of nano-albumin with the different concentrations on the cultured lymphocyte Fig (2). The same results were previously published by Namasivayan and Robin [33] who evaluated the genotoxic effects of nano-albumin by incubating the prepared nanoparticles with the genomic DNA for $24 \mathrm{~h}$ and then they subjected the DNA for electrophoresis. They found that the genomic DNA was not fragmented. 

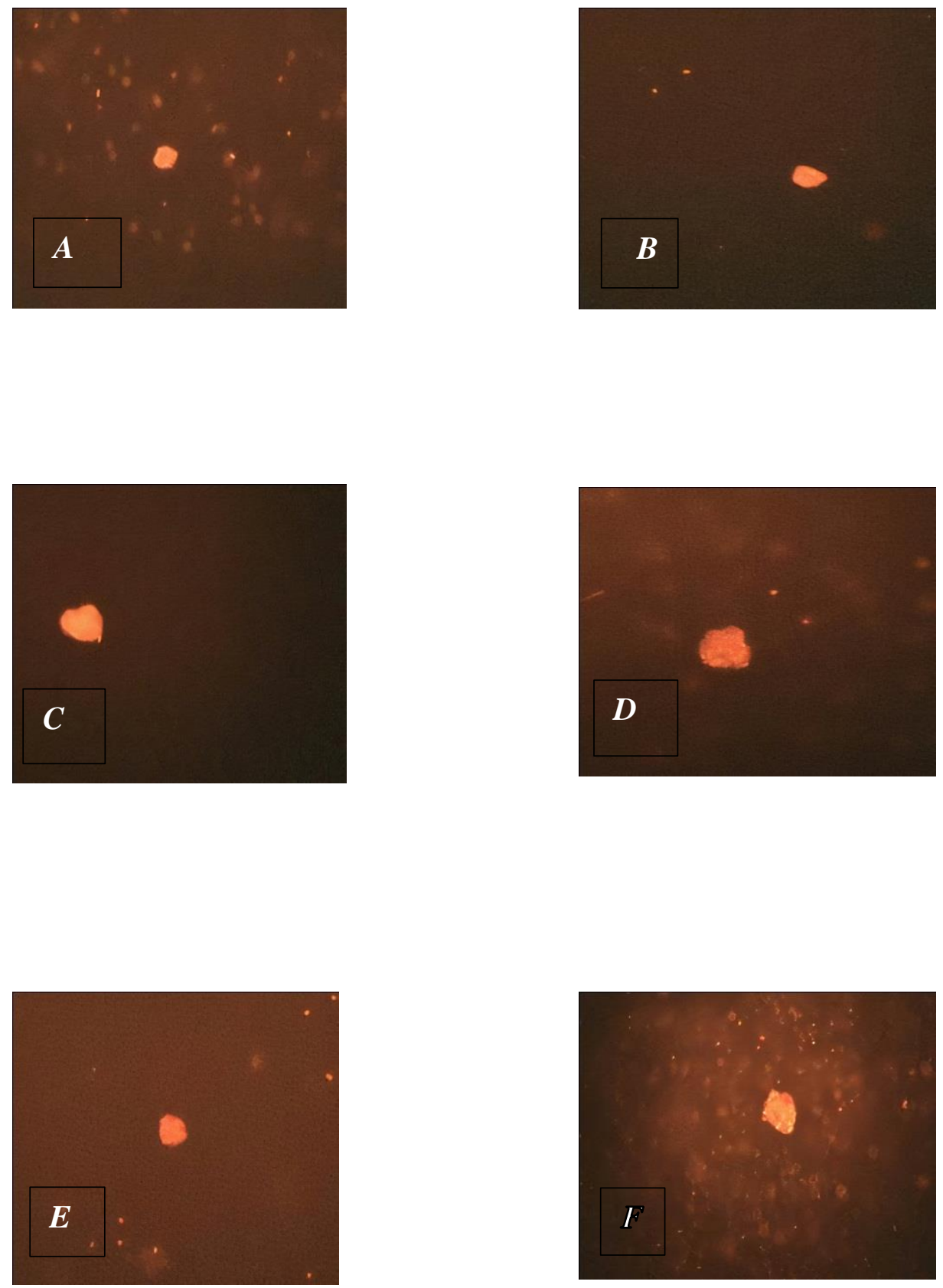

Fig. ( 2 ): Image of comet assay show no DNA damage in different groups since no DNA fragments outside the nucleus as in (A) control group and in all treated groups (B), (C), (D), (E) and (F) with different concentrations of prepared nano-albumin.

\subsection{Lymphocyte proliferation activity using MTT reduction assay:}

Lymphocyte proliferation activity assay showed significant stimulation of lymphocyte proliferation in case of both $100 \mu \mathrm{g} / \mathrm{ml}$ and $0.0001 \mu \mathrm{g} / \mathrm{ml}$ concentrations. Other evaluated concentrations of nano-albumin have no effect on lymphocyte as showed in table (2). 
Because of their biodegradable properties and their ability to stimulate immune system, polymeric nanoparticles have been widely explored as new vaccine platforms which could provide continued antigen release after vaccine organization $[32 ; 34]$. Another publication reported that when the albumin has been incubated with osteoblastic cell at conc. $(1 \mathrm{mg} / \mathrm{ml})$ for $24 \mathrm{~h}$, the cell proliferation was enhanced and this may be because different protein kinases that are partly mediated the signals of intracellular pathway [35]. So that, the albumin nanoparticles is suggestive for use as a carrier system to enhance antigen processing and/or as an immune stimulant adjuvant to enhance and promotes the response of immune system.

Table (2): Mean \pm SE of Lymphocyte proliferation test readings of the effect immune reduclatory of different concentrations of prepared albumin nanoparticles on lymphocytes cell.

\begin{tabular}{|l|l|}
\hline Conc. of nano-albumin $\boldsymbol{\mu g} / \mathbf{~ m l}$ & Mean $\pm \mathbf{S E}$ \\
\hline \hline Control & $1.814 \pm 0.097$ \\
\hline \hline 10000 & $1.07 \pm 0.173$ \\
\hline 1000 & $0.998 \pm 0.101$ \\
\hline 100 & $1.853 \pm 0.284^{*}$ \\
\hline 10 & $1.30 \pm 0.386$ \\
\hline 1 & $1.73 \pm 0.321$ \\
\hline 0.1 & $0.933 \pm 0.006$ \\
\hline \hline 0.01 & $1.067 \pm 0.034$ \\
\hline \hline 0.001 & $1.37 \pm 0.194$ \\
\hline \hline 0001 & $1.814 \pm 0.127^{*}$ \\
\hline \hline
\end{tabular}




\section{Conclusion:}

This study utilized a method of obtaining Bovine Serum Albumin (BSA) nanoparticles. The in vitro safety of albumin nanoparticles has been demonstrated by the cytotoxicity and genotoxicity studies which indicated that there is no recorded toxic effect of albumin nanoparticles on living cell.

\section{References:}

[1] M. Z. Troncarelli, H. M. Brandão, J. C. Gern, A. Guimarães and H. Langoni, "Nanotechnology and antimicrobials in veterinary medicine", In: Microbial pathogens and strategies for combating them: Science, Technology and Education (A. Méndez-Vilas, Ed.) FORMATEX (2013): 543-556L.

[2] M. T. Elshamy, S. M. ELKhallal, S. M. Husseiny, K. Y. Farroh "Application of nano-chitosan NPK fertilizer on growth and productivity of potato plant." Journal of Scientific Research in Science 36: (2019) 424-441.

[3] N.M. Hamed , A.B.EL-Bialy, S.S. Hamed, S. Abd El-Mongy " Spectroscopic studies of nanometric Zinc Oxide." Journal of Scientific Research in Science 35: (2018) 287-297

[4] L. Wang, Chen Hu, Longquan Shao " The antimicrobial activity of nanoparticles: present situation and prospects for the future." International Journal of Nanomedicine.12: (2017) 1227-1249.

[5] N. El-Tohamy, M. Attia, S. M. Easa, N. M. Awad "Characterization and evaluation of nanocomposites chitosan-multiwalled carbon nanotubes as broadspectrum antibacterial agent." Journal of Scientific Research in Science 35: (2018) 16-27.

[6] L. Zhang, D. Pornpattananangkul, C.-M.J HU, C.-M Huang "Development of Nanoparticles for Antimicrobial Drug Delivery." Current Medicinal Chemistry, 17: (2010) 585-594.

[7] J. Mcmillan, E. Batrakova, H.E. Gendelman, "Cell Delivery of Therapeutic Nanoparticles." Progress in Molecular Biology and Translational Science 104: (2011) 563-601.

[8] F. Kratz, B. Elsadek. "Clinical impact of serum proteins on drug delivery." Control Release 161: (2012) 429-445.

[9] R. Naveen, K. Akshata, S. Pimple and P. Chaudhari, "A review on albumin as drug carrier in treating different diseases and disorders."Progressive Education Society's Modern College of Pharmacy 7: (2016) 11-15

[10] W. Lohcharoenkal, L. Wang, Y.C. Chen, Y. Rojanasakul, "Protein nanoparticles as drug delivery carriers for cancer therapy." BioMed research international. (2014)1-12. doi: 10.1155/2014/180549.

[11] V. Prabhu ,S. Uzzaman , V. Mariammal , B. Grace , C. Guruvayoorappan, "Nanoparticles in drug delivery and cancer therapy: the giant rats tail." Journal of Cancer Therapy 2: (2011) 325-334. 
[12] A. Akbarzadeh,R.R. Sadabady, S. Davaran, S.W. Joo,N. Zarghami, Y. Hanifehpour, et al. "Liposome: classification, preparation, and applications." Nanoscale research letters 8: (2013) 1-9.

[13] N. Jain, A. Bhargava, M. Rathi, R. V. Dilip, J Panwar." Removal of protein capping enhances the antibacterial efficiency of biosynthesized silver nanoparticles." PLoS One 10: (2015) 1-19.

[14] X. Wang, M. Li, J. Wang and Y. Cao "The Effect of Nano-Albumin Paclitaxel on the Early Postoperative Recurrence of Primary Liver Cancer" Journal of Nanoscience and Nanotechnology 20: (2020) 7283 -7288.

[15] A. Aljabali A.A., H. Bakshi A., F. Hakkim L., Y. Haggag A., K. Al-Batanyeh M., M. Al Zoubi S., B. Al-Trad, M. Nasef M., S. Satija, M. Mehta, K. Pabreja, V. Mishra, M. Khan, S. Abobaker, I. Azzouz M., H. Dureja, R. Pabari M., A. Dardouri A. K., P. Kesharwani, G. Gupta, S. Shukla D., P. Prasher, N. Charbe B., P. Negi, D. Kapoor N., D. Chellappan K., M. da Silva W., P. Thompson, K. Dua, P. McCarron and M. Tambuwala M. "Albumin Nano-Encapsulation of Piceatannol Enhances Its Anticancer Potential in Colon Cancer Via Downregulation of Nuclear p65 and HIF-1 $\alpha . "$ Cancers (2020)12(1):113, doi: 10.3390/cancers 12010113 .

[16] S. Abbasi, A. Paul, W. Shao, S. Prakash, "Cationic Albumin Nanoparticles for Enhanced Drug Delivery to Treat Breast Cancer: Preparation and In Vitro Assessment" Drug Delivery 2012: (2012) 686108-6861166.

[17] J. Gong, M. Huo, J. Zhou, Y. Zhang, X. Peng, D. Yu, H. Zhang, J. Li " Synthesis, characterization, drug-loading capacity and safety of novel octyl modified serum albumin micelles" International Journal of Pharmaceutics 376: (2009) 161-168.

[18] G. Rai-Elbalhaa, J. L. Pellerin, G. Bodin, H. A. Abdullah, and H. Hiron," lymphocytic transformation assay of sheep peripheral blood lymphocytes. A new rapid and easy to read technique." Microbiol., Inf. Dis., 8: (1985) 311-318.

[19] S. Patel . P. Patel . S. R. Bakshi " Titanium dioxide nanoparticles: an in vitro study of DNA binding, chromosome aberration assay, and comet assay" Cytotechnology, 2: (2017) 245-263.

[20] P. Apostolou, M. Toloudi, E. Kourtidou, G. Mimikakou, L. Vlachou, M. Chatziioannou and L. Papasotiriou, "Use of the comet assay technique for quick and reliable prediction of in vitro response to chemotherapeutics in breast and colon cancer" Journal of Biological Research-Thessaloniki 1: (2014) 21-14.

[21] G.W. Snedecor, and W.G. Cochran, (1982) Statistical Methods. 7th Edition, Iowa State University Press, Towa, 511.

[22] F. M. Menger and B. M. Sykes, "Anatomy of a coacervate", Langmuir, 14: (1998) 4131-4137.

[23] W. Lin, A. G. Coombes, M. C. Davies, S. S. Davis, and L. Illum, "Preparation of sub-100 nm human serum albumin nanospheres using a $\mathrm{pH}$-coacervation method," Journal of Drug Targeting 1: (1993) 237-243.

[24] K. Langer, S. Balthasar, V. Vogel, N. Dinauer, H. Von Briesen and D. Schubert, "Optimization of the preparation process for human serum albumin (HSA) nanoparticles," International Journal of Pharmaceutics 257: (2003) 169-180. 
[25] M.M. Rahimnejad, G. D, Jahanshahi, Najafpour "Production of biological nanoparticles from bovine serum albumin for drug delivery" African Journal of Biotechnology, 5 (20): (2006) 1918-1923.

[26] I. Luis de Redína, C. Boierob, M. Cristina M. Ohárrizc, M. Agüerosa,R. Ramosd, I. Peñuelasd, D. Allemandib, J. M. Llabotb, J. M. Irachea, "Human serum albumin nanoparticles for ocular delivery of bevacizumab" International Journal of Pharmaceutics 541: (2018) 214-223.

[27] F. Kratz, "Albumin as a drug carrier: design of prodrugs, drug conjugates and nanoparticles,” Journal of Controlled Release 132 :2008) 171-183.

[28] H. D. Singh, G.Wang, H. Uluda g, and L. D. Unsworth, "Poly- L-lysine-coated albumin nanoparticles: stability, mechanism for increasing in vitro enzymatic resilience, and siRNA release characteristics," Journal of Acta biomaterialia.6: (2010) 4277- 4284.

[29] V. P. Torchilin, R. Rammohan, V.Weissig, and T. S. Levchenko "TAT peptide on the surface of liposomes affords their efficient intracellular delivery even at low temperature and in the presence of metabolic inhibitors," Proceedings of the National Academy of Sciences of the United States of America 98: (2001) 87868791.

[30] Sana Abbasi 1, Arghya Paul, Satya Prakash "Investigation of siRNA-loaded polyethylenimine-coated human serum albumin nanoparticle complexes for the treatment of breast cancer." Journal of Cell biochemistry and biophysics. 61(2):(2011) 277-87. doi: 10.1007/s12013-011-9201-9.

[31] Rongzuo Xu, Michael Fisher, and R. L. Juliano "Targeted Albumin-Based Nanoparticles for Delivery of Amphipathic Drugs." Journal of Bioconjugate Chemistry. 22: (2011) 870-878.

[32] Natalia Ingrid Oliveira da Silvaa, Ezequiel Aparecido Salvadora, Isabella Rodrigues Francoa, Gabriel Augusto Pires de Souzaa, Stella Maria de Souza Moraisa, Raissa Prado Rochaa, Rômulo Dias Novaesb, Patrícia Paiva Corsettia,c, Luiz Cosme Cotta Malaquiasa, Luiz Felipe Leomil Coelhoa," Bovine serum albumin nanoparticles induce histopathological changes and inflammatory cell recruitment in the skin of treated mice." Biomedicine \& Pharmacotherapy 107: (2018) 1311-1317.

[33] S. Karthick Raja Namasivayam and A. T. George Robin "Preparation of nanoalbumin-flutamide (Nab-flu) conjugate and evaluation of its in vitro drug control release, anticancer activity and genotoxicity." Indian Journal of Experimental Biology 56: (2018) 171-179.

[34] L. Zhao, A. Seth, N. Wibowo, C.X. Zhao, N. Mitter, C. Yu, A.P.J. Middelberg, "Nanoparticle vaccines", Vaccine 32: (2014) 327-337.

[35] Koichi Ishida and Masayoshi Yamaguchi " Role of albumin in osteoblastic cells: Enhancement of cell proliferation and suppression of alkaline phosphatase activity" International Journal of Molecular Medicine 14: (2004) 1077-1081. 


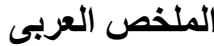

\section{الالبيومين النانومترى كحامل للمضاد الحيوى لعلاج العدوى البكتيرية}

كان الهدف من هذه الدراسة هو تحضير وتوصيف جزيئات الالبيومين النانونية لاستخدامها لاحقا كناقل للادوية وذللك لحل مشاكل كثثرة تو اجهه الاستخدام التقليدى لبعض المضادات الحيوية و التعزيز من فرصة العلاج

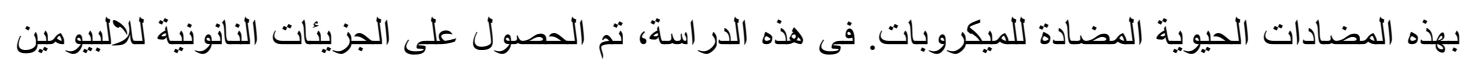
المستخلص من مصل صغار الابقار باستخدام طريقة الفصل التماسكى (حيث يتم فصل البروتين بين طبقتين

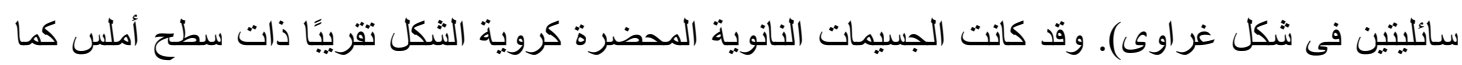
تحدد باستخدام المجهر الاليكترونى الناقل، وحجمها يتر اوح ما بين 70ذ10 نانومتر وسطحها يحمل شحنة سالبة. بالإضافة إلى ذلك، تم إثبات سلامة جسيمات الألبومين النانوية في المختبر، حيث أثنارت كل من الدراسات السمية الخلوية و السمية الجينية إلى أنه لا يوجد نأثثير سام ملاحظ لجزيئات الالبيومين النانونية على خلايا كرات الدم البيضاء الليمفاوية. كما أظهرت النتائج ان جزيئات الالبيومين النانونية تعزز من استجابة الجهاز المناعى. لئه 